\section{Ibsen i bilder}

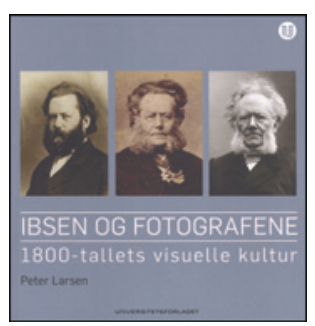

Peter Larsen

Ibsen og fotografene

1800-tallets visuelle kultur. 239 s, ill.

Oslo: Universitetsforlaget, 2013. Pris NOK 349 ISBN 978-82-15-02015-0
Er det ingen grense for hvilke prosjekter som skal settes i gang i Henrik Ibsens navn? Nå foreligger en bok med tittelen Ibsen og fotografene, en gjennomgang av de ca. 100 fotografiene som finnes av dikteren. Men boken er langt mer interessant enn som så. Forfatteren Peter Larsen, professor ved Institutt for informasjons- og medievitenskap, Universitetet i Bergen, har favnet det som i undertittelen kalles 1800-tallets visuelle kultur. Det omfatter både den kulturhistoriske og fotohistoriske sammenhengen bildene ble til i. Det er blitt en utmerket bok.

De første fotografiene av Ibsen byr på flere problemer. De er alle tatt tidlig i 1860-årene, men noen eksakt datering er vanskelig, og også ellers er det mye uklart ved dem. Det aller første er tilskrevet Edvard Larssen (1840-94), og det oppsummeres slik: «Til sjuende og sist må vi bare konstatere at historien om Ibsen og fotografene begynner med en fotograf som stort sett ikke fotograferte, og med et bilde han kanskje ikke har tatt» (s. 21). Fotografen av det andre bildet skal være Peter Petersen (1835-94). Man trodde lenge at dette fotografiet var forsvunnet, slik jeg selv har angitt det i en artikkel i Tidsskriftet med opplysninger fra «Hundreårsutgavens» bildebind (1). Men så viser det seg at fotografiet finnes likevel. Det ble funnet i Riksarkivet og nevnt første gang av medisineren Otto Lous Mohr i 1953 (s. 22). Det tredje Ibsen-portrettet er trolig tatt av Daniel Georg Nyblinn (1826-1910). Larsen skriver: «Det er like mange mysterier knyttet til dette bildet som til de to andre tidligere Ibsen-portrettene» (s. 31). Dette fotografiet er spesielt interessant. Ibsen sitter i Napoleons-positur, jakken har huller på skulderen, og skjortemansjetten er loslitt. Men selv om det var slik fatt med Ibsen i 30-årsalderen, gikk han altså likevel til fotografen.

De siste portrettfotografiene som ble tatt av Ibsen, var et par stereografier i 1905 på oppdrag fra det amerikanske firmaet Underwood \& Underwood. Jeg har hatt et anstrengt forhold til disse bildene, fordi de skal ha blitt tatt av en utenlandsk turist eller journalist som trengte seg inn i den syke Ibsens leilighet. Ut fra Ibsens bistre uttrykk er det lett å tro at det kan ha vært slik. Men Larsen mener at det ikke var tale om noen inntrenger, men et opptak som var avtalt på forhånd (s. 165, 224).

Larsens bok preges av et solid arbeid med kildene. Notene dekker 13 tettskrevne sider. Men skjønnhetsfeil finnes. Han skriver at Ibsen etter sykdommen våren 1900 måtte oppgi sin daglige spasertur til Grand Café. «I stedet ble det en tur i hestevogn sammen med en lege.» (s. 180). Det er riktig at fotografen Anders Beer Wilse (1865-1949) hevdet dette i en minnebok over 40 år senere. Men så vidt jeg vet, finnes ingen dokumentasjon for at en lege fulgte Ibsen på disse turene. Trolig var det Ibsens trofaste massør, Arnt Dehli, som bisto dikteren (2).

\section{Erlend Hem}

Tidsskriftet

\section{Litteratur}

1. Hem E. Var det lege Ibsen ville bli? Tidsskr Nor Lægeforen 2006; 126: 3295-6.

2. Hem E. Ibsen på kjøretur. Tidsskr Nor Lægeforen 2006; 126: 1449.

\section{Sykdom som helsekilde}

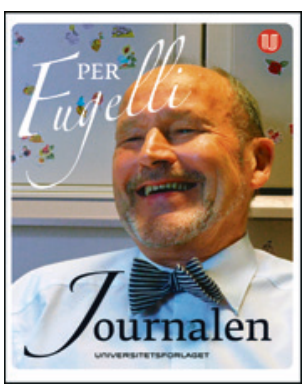

\author{
Per Fugelli \\ Journalen \\ 272 s. Oslo: Universitetsforlaget, 2013. \\ Pris NOK 349 \\ ISBN 978-82-15-02238-3
}

Målgruppen er alle som er interessert i helse og helsepolitikk, og det er vel de fleste av oss. Per Fugelli leverer varene i kjent stil med friske fraspark, filosofiske betraktninger og ikke minst godt humør. Som han skriver i sitt forord, hyller han «sykdom som helsekilde», og innholdet beviser den teorien. For de som har hatt gleden av å høre og lese Per Fugelli tidligere, er det ikke banebrytende nytt innhold, men den originale formen med én «personlig» og én «medisinsk» journal gjør at leseren, og særlig leger, blir utfordret til refleksjon.

Temaet er i utgangspunktet dystert med nedtegnelser knyttet til et alvorlig sykdomsforløp. Likevel er det en vilter og leken bok. Etter et kort forord får vi ta del i Fugellis «personlige journal» gjennom flere år med kreftsykdom. Dagboken viser oss stort og smått i pasientens liv, tanker og meninger fra mai 2010 til mars 2013.

Forfatteren legger ikke fingrene imellom når det gjelder sine politiske standpunkter, enten det gjelder terrorangrep, FrP, frihetsbegrepet eller samfunnets behandling av romfolk. Ikke alle vil være enig $i$ alle påstandene, men det er heller ikke forfatterens hensikt. Det sentrale, slik jeg leste det, er at summen av enkelthistoriene og meningsytringene blir en ideologisk helhet som vi alle burde reflektere over. I god, sokratisk ånd deler forfatteren av sin erfaring ved å få oss til å tenke og stille spørsmål selv.

For leger som leser denne teksten, er kanskje det mest spennende virkemidlet når man etter litt over 200 sider med sprudlende lesning i den personlige journalen kommer over i den medisinske delen. Der kan man lese nedtegnelser av legekunst på høyt nivå. En del av meg er stolt over alt de fantastiske kreftlegene har fått til, en annen del av meg humrer over alt det andre hos pasienten kreftlegene har oversett. Pasientens håp, gleder og sorger blir kort oppsummert slik: «Sosialt: Gift, to voksne barn. Professor i sosialmedisin.»

Per Fugelli er ingen typisk pasient når han deltar i TV-debatter eller holder foredrag for Arbeiderpartiet. Han har likevel til felles med alle andre pasienter at hans liv dreier seg om så mye mer enn størrelsen på en metastasesuspekt lesjon eller andre diagnostiske funn.

Boken inneholder ikke ny kunnskap, men den minner oss på at vår oppgave i møte med en pasient er mer enn bare tekniske undersøkelser og behandling. Vi må ha en helsetjeneste som ikke bare er flink, men også snill. Samfunnet må være raust, og menneskene er en flokk som gir hverandre frihet.

\section{Robin Martin Kåss}

Lege og politiker, Porsgrunn 